\title{
Coexpression of Phosphotyrosine-containing Proteins, Platelet-derived Growth Factor-B, and Fibroblast Growth Factor-1 In Situ in Synovial Tissues of Patients with Rheumatoid Arthritis and Lewis Rats with Adjuvant or Streptococcal Cell Wall Arthritis
}

\author{
Hajime Sano, Kurt Engleka, * Peter Mathern, Timothy Hla, * Leslie J. Crofford, Elaine F. Remmers, \\ Carole L. Jelsema, Ellen Goldmuntz, Thomas Maciag, * and Ronald L. Wilder \\ Arthritis and Rheumatism Branch, National Institute of Arthritis and Musculoskeletal and Skin Disease, National Institutes of Health, \\ Bethesda, Maryland 20892; and *Department of Molecular Biology, Holland Laboratory, \\ American Red Cross, Rockville, Maryland 20855
}

\begin{abstract}
Fibroblast growth factor (FGF)-1 and PDGF-B-like factors have been implicated in the pathobiology of $R A$ and animal models of this disease. Since the receptors for FGF-1 and PDGF are tyrosine kinases, we examined the expression of tyrosine phosphorylated proteins (phosphotyrosine, P-Tyr) in synovial tissues from patients with RA and osteoarthritis (OA), and rats with streptococcal cell wall (SCW) and adjuvant arthritis (AA). Synovia from patients with RA and LEW / $N$ rats with SCW and $A A$ arthritis, in contrast to controls, stained intensely with anti-P-Tyr antibody. The staining colocalized with PDGF-B and FGF-1 staining. Comparative immunoblot analysis showed markedly enhanced expression of a 45kD P-Tyr protein in the inflamed synovia. Treatment with physiological concentrations of dexamethasone suppressed both arthritis and P-Tyr expression in AA. P-Tyr was only transiently expressed in athymic nude Lewis rats and was not detected in relatively arthritis-resistant F344/ $\mathrm{N}$ rats. These data suggest that (a) FGF-1 and PDGF-B-like factors are upregulated and may induce tyrosine phosphorylation of proteins in vivo in inflammatory joint diseases, $(b)$ persistent high level P-Tyr expression is T lymphocyte dependent, correlates with disease severity, and is strain dependent in rats, $(c)$ corticosteroids, in physiological concentrations, downregulate P-Tyr expression in these lesions. (J. Clin. Invest. 1993. 91:553-565.) Key words: glucocorticoids • growth factors • fibroblast growth factor-1 • inflammation - phosphorylation • platelet-derived growth factor
\end{abstract}

\section{Introduction}

Synovial tissues from patients with RA, as well as the joints of LEW/N rats with streptococcal cell wall (SCW) ${ }^{1}$ and adjuvant arthritis (AA), which are experimental models resembling RA,

Address correspondence and reprint requests to Ronald $\mathrm{L}$. Wilder, M.D., Ph.D., Building 10, Room 9N240, National Institute of Arthritis and Musculoskeletal and Skin Diseases, National Institutes of Health, Bethesda, MD 20892. Dr. Hajime Sano's present address is First Department of Internal Medicine, Kyoto Prefectural University of Medicine, Kamigyo-ku, Kyoto 602, Japan.

Received for publication 22 April 1992 and in revised form $13 \mathrm{Au}$ gust 1992.

The Journal of Clinical Investigation, Inc.

Volume 91, February 1993, 553-565 are characterized by diffuse and nodular mononuclear cell infiltration and massive hyperplasia of the stromal connective tissues. The hyperplastic connective tissues are comprised primarily of fibroblast-like cells and new blood vessels (1-4). These cells are the predominant cell types at sites of erosive synovial destruction of bone and cartilage. We have provided evidence suggesting that this highly invasive lesion resembles a localized, nonmetastatic neoplasm (1, 4-10).

We have also presented evidence implicating fibroblast growth factor (FGF)-1 (also called acidic FGF or HBGF-1) and PDGF-B-like factors in these inflammatory joint diseases (1113). Both are potent mitogenic agents for synovial fibroblasts. FGF-1, in addition, directly stimulates angiogenesis in vivo (14). Synovial tissues of RA patients express high levels of FGF-1 and PDGF-B-like factors compared with the synovia of osteoarthritis (OA) patients, a noninvasive joint disease (1113). These inflammatory lesions express high levels of protooncogenes such as c-myc (9) and c-fos (11). FGF-1 and PDGF are also known to stimulate the expression of these nuclear regulatory factors $(14,15)$. These observations are consistent with the view that the interaction of these growth factors with their receptors in arthritic joints play a role in generating the invasive tumor-like behavior of RA synovial connective tissues.

Growth factors such as FGF-1 and PDGF bind to specific high affinity cell receptors on a variety of cell types (14-17). In addition to the stimulation of $c-m y c$ and $c-f o s$, in vitro studies of the interaction of these growth factors with their receptors have shown induction of tyrosine kinase activity and the generation of numerous tyrosine phosphorylated proteins (14-17). These data predict that enhanced expression of tyrosine phosphorylated proteins should develop in inflammatory joint diseases.

To confirm our prediction and to provide further support for our hypotheses regarding the important role of FGF-1 and PDGF-B-like factors in promoting the tumor-like behavior of rheumatoid synovial membranes, we studied tyrosine phosphoprotein expression in vivo in $\mathrm{RA}, \mathrm{OA}$, as well as in the two experimental rat models of arthritis. Our data are clearly consistent with the view that FGF-1 and PDGF-B-like factors are active in vivo in these inflammatory lesions and may transduce some of their effects through phosphorylation of tyrosine.

1. Abbreviations used in this paper: $\mathrm{AA}$, adjuvant arthritis; $\mathrm{EGF}$, epithelial growth factor; FGF, fibroblast growth factor; $\mathrm{H}$ and $\mathrm{E}$, hematoxylin and eosin; HPA, hypothalmic-pituitary-adrenal axis; OA, osteoarthritis; SCW, streptococcal cell wall. 


\section{Methods}

Human tissue specimens. Synovial specimens were obtained from the joints of patients with RA, OA, or a traumatic injury intraoperatively at time of arthroscopic biopsy or total joint replacement. The specimens were preserved in $10 \%$ formalin, embedded in paraffin, and sectioned $(6 \mu \mathrm{m})$ onto gelatin-coated slides. All 18 RA patients met the 1987 American College of Rheumatology criteria for the classification of RA (18), and all 12 OA patients met American College of Rheumatology criteria (19). Histologic sections from some of these tissues have also been used for other studies $(11,12)$.

Animals. Euthymic, virus antibody-free, inbred $\mathrm{LEW} / \mathrm{N}$ and F344/N female rats were obtained from Harlan Sprague Dawley, Inc. (Indianapolis, IN). Congenitally athymic nude LEW.rnu/rnu rats were obtained from the Small Animal Section of the Veterinary Resources Program of the National Center for Research Resources at the National Institutes of Health, Bethesda, MD. The rats were housed in cages with filter tops (Lab Products, Maywood, NJ) in an environment free of known microbial pathogens. The rats were $\sim 6$ wk old and weighed $80-100 \mathrm{~g}$ at the initiation of each experiment.

Induction of streptococcal and adjuvant arthritis. The preparation of cell wall peptidoglycan-polysaccharide fragments from group A streptococci and the induction of polyarthritis have been described ( 20 , 21 ). Briefly, a sterile aqueous suspension of sonicated SCW fragments in PBS, pH 7.4, was injected intraperitoneally into rats at a dose equivalent to $20 \mu \mathrm{g}$ of cell wall rhamnose per gram body weight. This dose has been shown previously to induce acute and chronic polyarthritis, in LEW/N female rats, and acute, but not chronic polyarthritis in athymic nude LEW.rnu/rnu rats with $100 \%$ incidence (4). Relatively arthritis-resistant $\mathrm{F} 344 / \mathrm{N}$ female rats were also injected. Rats injected with SCW (day 0 ) were killed in pairs at days 1-4 and 28.

AA was induced in female $\mathrm{LEW} / \mathrm{N}$ rats and clinically scored as described (22). $200 \mu \mathrm{l}$ of a suspension of pulverized Mycobacterium butyricum (Difco Laboratories, Detroit, MI) at $10 \mathrm{mg} / \mathrm{ml}$ in mineral oil (paraffin oil, heavy; Fisher Scientific Co., Pittsburgh, PA) were injected in $25-\mu \mathrm{l}$ aliquots in eight different locations, four on each side, of the intradermal cervical/periscapular region with a 25-gauge needle while the animals were under light anesthesia (day 0 ). Athymic nude LEW.rnu/rnu and arthritis-resistant F344/N rats, which usually do not develop clinically apparent AA, were also injected with the adjuvant suspension. Rats injected with adjuvant (day 0 ) were killed in pairs at 2-d intervals throughout the preclinical stages of disease until the development of maximal clinical arthritis (day 18). Hindfoot specimens were preserved in $10 \%$ formalin, decalcified in EDTA, embedded in paraffin, and sectioned $(6 \mu \mathrm{m})$ onto gelatin-coated microscope slides.

Glucocorticoid treatment of adjuvant arthritic $L E W / N$ rats. The LEW/N rats were implanted intraperitoneally with a mini-osmotic pump (Alzet 2002; Alza Corp., Palo Alto, CA) as described by Lorberboum-Galski et al., on the day of injection of adjuvant (23). Either dexamethasone (Sigma Chemical Co., St. Louis, MO) dissolved in $10 \%$ ethanol $/ 90 \%$ normal saline at $0.167 \mathrm{mg} / \mathrm{ml}(0.02 \mu \mathrm{g} / \mathrm{g}$ body wt $)$ or vehicle alone was administered to rats injected with adjuvant. Rats in each group were assessed for arthritis and killed in pairs on days $0,4,8$, and 12 . The tissues were prepared for immunohistology and hematoxylin and eosin ( $\mathrm{H}$ and $\mathrm{E}$ ) staining as described above.

Purification of FGF-1 antibody. Polyclonal antiserum against recombinant human FGF-1 was prepared in a rabbit and affinity-purified on recombinant human FGF-1 coupled to cyanogen bromide-activated Sepharose 4B ( Pharmacia Fine Chemical, Uppsala, Sweden) as described previously (11). Immunoblot analysis of the affinity-purified antibody demonstrated that FGF-1 antibody recognized FGF-1 but not FGF-2 (basic FGF) (11).

Preparation and characterization of anti-P-Tyr sera. Anti-P-Tyr antisera were prepared essentially as described by Ek and Heldin (24). Briefly, $2 \mathrm{mg}$ of P-Tyr was coupled to $10 \mathrm{mg}$ of bovine immunoglobulin by incubation for $24 \mathrm{~h}$ at $22^{\circ} \mathrm{C}$ with constant agitation in the presence of $20 \mathrm{mg}$ of $\mathrm{N}$-ethyl- $\mathrm{N}$-(3-dimethylamino-propyl) carbodiimide in a final vol of $1 \mathrm{ml}$ of PBS. After coupling, the conjugate was dialyzed exhaustively at $22^{\circ} \mathrm{C}$ against PBS. Female New Zealand white rabbits were immunized by multiple intradermal injections with $200 \mu \mathrm{g}$ of the P-Tyr-immunoglobulin conjugate in $0.5 \mathrm{ml}$ of PBS mixed with an equal volume of Freund's complete adjuvant. The rabbits were boosted every $3 \mathrm{wk}$ with the same amount of antigen suspended in an equal volume of Freund's incomplete adjuvant. The rabbits were bled after a total of three injections and tested for production of anti-P-Tyr antibody. Rabbit antisera that were positive for reactivity to P-Tyr-containing proteins were affinity purified by absorption to and elution from phosphotyramine-Sepharose (16). The IgG fraction of rabbit antisera was affinity purified by rec-Protein $\mathrm{G}$ prepacked column (Zymed Laboratories, Inc., San Francisco, CA).

Anti-P-Tyr monoclonal antibody for immunohistochemistry was also purchased from Oncogene Science, Inc., Manhasset, NY. This antibody reacted with phosphotyrosine-containing proteins such as the receptors for epithelial growth factor (EGF), PDGF, and insulin, but did not cross-react with phosphoserine, phosphothreonine, or phosphohistidine nor with a variety of other phosphorylated molecules, including ribose phosphate, IMP, AMP, and ATP (25).

Immunohistochemistry. P-Tyr, FGF-1, and PDGF-B chain antigens were demonstrated by the use of saturating amounts of antibodies against P-Tyr, FGF-1, or PDGF in combinations with immunoperoxidase staining with a Vectastain ABC kit (Vector Laboratories Inc., Burlingame, $\mathrm{CA})$ as described previously $(11,12)$. All subsequent procedures were performed at room temperature. The sections were deparaffinized, and endogenous peroxidase activity was exhausted by incubating in $0.3 \%$ peroxide in methanol for $45 \mathrm{~min}$. The sections were preincubated with $0.1 \%$ BSA in PBS for $20 \mathrm{~min}$ and with diluted goat serum (1:66.7; Vector Laboratories) or horse serum (1:66.7; Vector Laboratories) for $20 \mathrm{~min}$. The sections were incubated in a humid chamber with rabbit anti-P-Tyr polyclonal antibody $75 \mu \mathrm{g} / \mathrm{ml}$, anti-PTyr monoclonal antibody (Oncogene Science, Inc.) $25 \mu \mathrm{g} / \mathrm{ml}$, anti-PTyr monoclonal antibody that was preincubated with purified $O$-phospho-L-tyrosine ( Sigma Chemical Co.) or $O$-phospho-D-tyrosine (Sigma Chemical Co.), affinity-purified anti-FGF-1 antibody $50 \mu \mathrm{g} / \mathrm{ml}$, affinity-negative fraction of anti-FGF-1 antibody $50 \mu \mathrm{g} / \mathrm{ml}$, monoclonal anti-PDGF-B antibody (Upstate Biotechnology, Inc., Lake Placid, NY) $75 \mu \mathrm{g} / \mathrm{ml}$, purified rabbit IgG (Jackson Immunoresearch Laboratories, Inc., West Grove, PA) $75 \mu \mathrm{g} / \mathrm{ml}$, purified mouse $\mathrm{IgG}_{1}-\kappa$ (MOPC 21; Sigma Chemical Co.) $25 \mu \mathrm{g} / \mathrm{ml}$, or purified mouse IgG $_{2 \mathrm{~b}}$ (Sigma Chemical Co.) $75 \mu \mathrm{g} / \mathrm{ml}$ for $30 \mathrm{~min}$, washed in PBS, and incubated with biotinylated goat anti-rabbit IgG or biotinylated horse antimouse IgG for $30 \mathrm{~min}$. The sections were further washed with PBS and incubated with an avidin and biotinylated horseradish peroxidase complex for $45 \mathrm{~min}$. Finally, the sections were washed and color was developed by immersing sections in a solution of $0.05 \% \mathrm{wt} / \mathrm{vol} 3,3^{\prime}$ diaminobenzidine tetrahydrochloride (Sigma Chemical Co.), $0.04 \%$ $\mathrm{wt} / \mathrm{vol}$ nickel chloride, and $0.01 \%$ hydrogen peroxide in $0.05 \mathrm{M}$ Tris, pH 7.4 for 2-7 min. The sections were counterstained with $0.5 \%$ light green SF (Roboz Surgical Instrument Co. Inc., Washington, DC). Positive staining was indicated by brownish-black deposits. Control stains with rabbit $\operatorname{IgG}$, mouse $\operatorname{IgG}_{1-\kappa}$, or the specific antibody absorbed with purified P-Tyr peptide were uniformly negative in all cases.

For each tissue specimen, the extent and intensity of staining with P-Tyr, FGF-1, or PDGF-B antibodies was graded on a scale of 0-4+ by a blinded observer on two separate occasions using coded slides, and an average score calculated. The observer assessed all tissue on the slides to assign the scores. A 4+ grade implies that all staining was maximally intense throughout the specimen, while 0 implies that staining was absent throughout the specimen. The microanatomical sites of staining were also recorded. Mononuclear cell infiltration was graded similarly on hematoxylin and eosin ( $\mathrm{H}$ and $\mathrm{E}$ ) stained sections cut from the same paraffin blocks used for antibody staining. A $4+$ grade implies that all tissue was intensely infiltrated with mononuclear cells, and 0 implies that mononuclear cell infiltration was absent throughout. This grading methodology has been used extensively in past studies (4, $9-13,26)$. 
Double antibody immunostaining. Sections were stained with the first antibody (FGF-1 antibody or PDGF-B antibody) using the peroxidase method as detailed above. The sections were next washed with PBS with $0.1 \%$ BSA for $20 \mathrm{~min}$ and then with diluted horse serum ( 1:66.7; Vector Laboratories) for $20 \mathrm{~min}$. The sections were incubated with monoclonal anti-P-Tyr in PBS (Oncogene Science, $(25 \mu \mathrm{g} / \mathrm{ml}$; Oncogene Science, Inc.) for $30 \mathrm{~min}$. After washing with PBS, the sections were incubated with biotinylated horse anti-mouse IgG in PBS for $30 \mathrm{~min}$. The sections were washed with PBS and incubated with Vectastain ABC-AP reagent (Vector Laboratories) for $45 \mathrm{~min}$. After
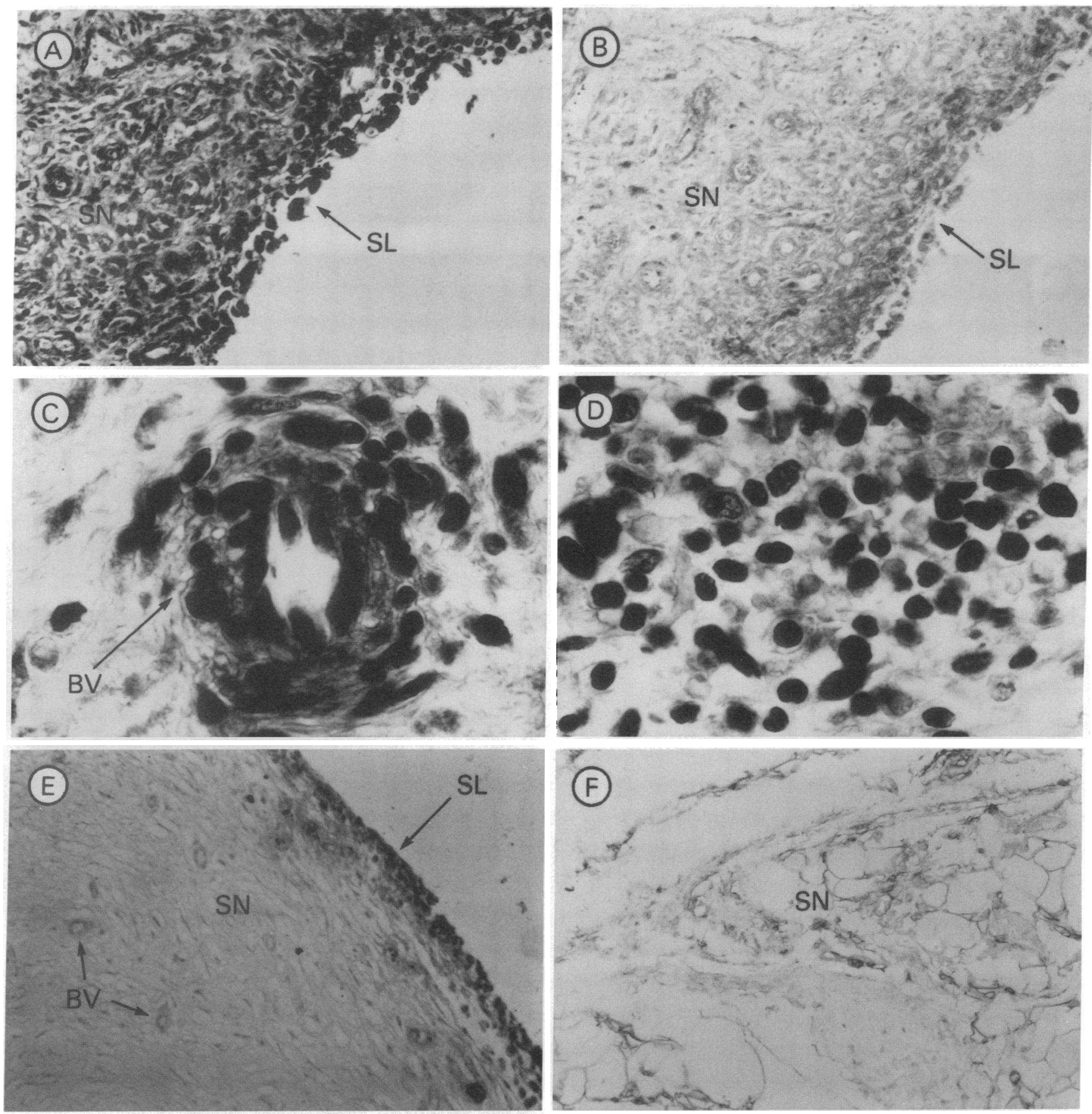

Figure 1. In situ P-Tyr immunostaining on synovium from patients with RA and OA. Representative sections from synovial tissues of patients with RA and OA and from "normal" synovial tissue were stained using rabbit anti-P-Tyr IgG ( $75 \mu \mathrm{g} / \mathrm{ml})$ as described in Methods. Positive staining was indicated by brownish-black deposits and background staining was light green on original sections. In this photograph, positive staining is indicated by black deposits. Control staining with normal rabbit $\mathrm{IgG}(75 \mu \mathrm{g} / \mathrm{ml})$ was uniformly negative. Similar data were obtained with anti-P-Tyr monoclonal antibody $(25 \mu \mathrm{g} / \mathrm{ml})$. Staining with normal mouse $\mathrm{IgG}_{1}$ or P-Tyr monoclonal antibody $(25 \mu \mathrm{g} / \mathrm{ml})$ that was adsorbed by preincubation with purified P-Tyr was also negative (data not shown). $(A),(C)$, and $(D)$, RA synovium stained with rabbit anti-P-Tyr $\operatorname{IgG}(\times 250$ on original photographs). ( $B)$ RA synovium stained with nonspecific rabbit IgG. $(E)$ OA synovium stained with rabbit anti-P-Tyr IgG $(\times 250$ on original photograph $) .(F)$ Normal synovial tissue stained with rabbit anti-P-Tyr IgG $(\times 250$ on original photograph $)$. The labels denote synovial lining cell layer $(S L)$, sublining synovial tissue cells $(S N)$, and blood vessels $(B V)$. 

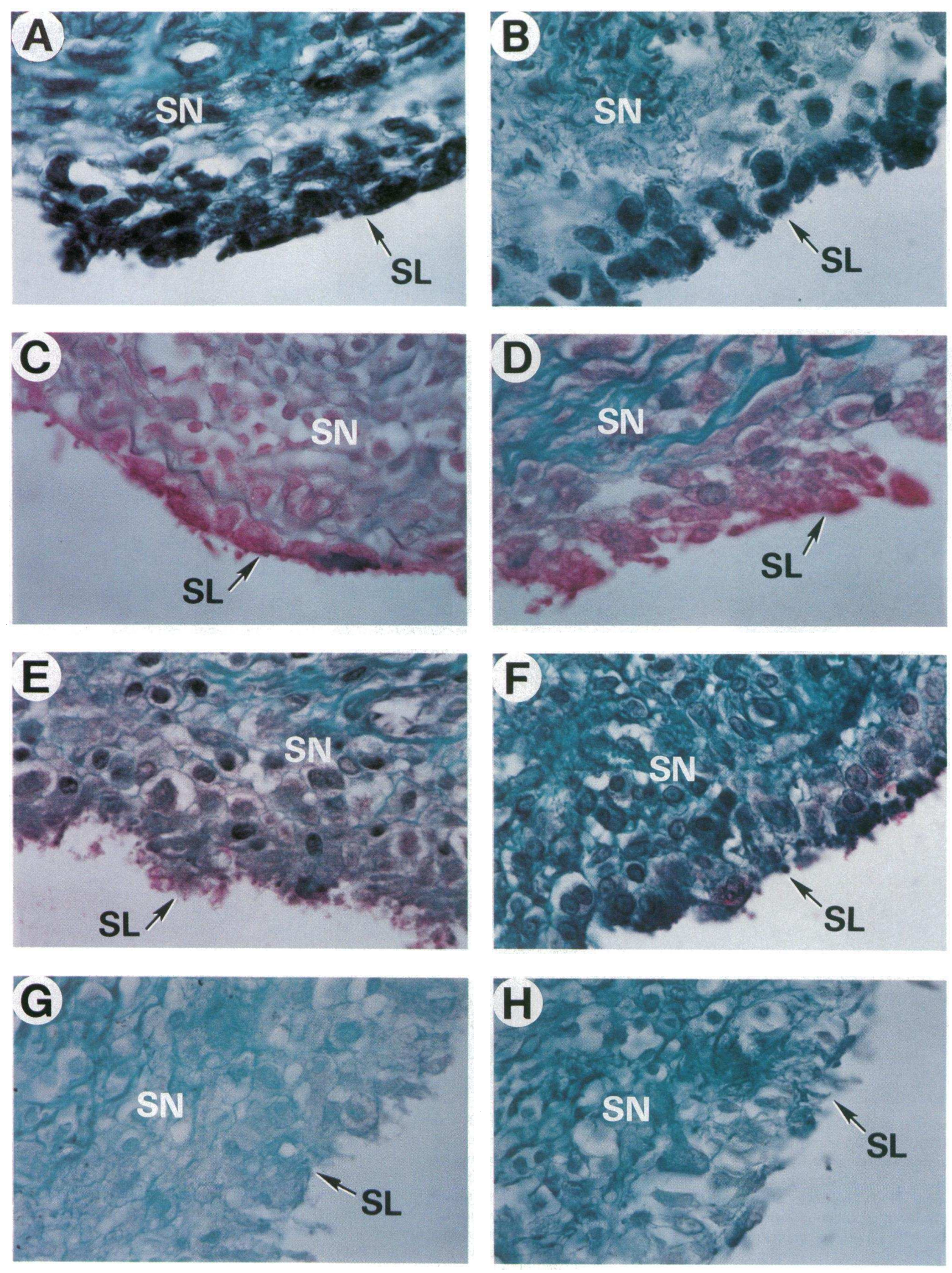
washing with PBS, color was developed by exposure to the alkaline phosphatase substrate solution for 15-30 min. Counterstaining was done with $0.5 \%$ light green SF. Positive staining for the alkaline phosphatase method was indicated by red deposits. Controls stained with affinity-negative anti-FGF-1, mouse $\mathrm{IgG}_{2 b}$, or mouse $\operatorname{IgG}_{1-\kappa} \times$ were uniformly negative (light green).

Immunoblot analysis. For anti-P-Tyr immunoblotting analysis, synovial tissues were quickly excised from the ankle joints of LEW/N rats at day 0 , day 3 after injection with SCW, and day 18 after injection with adjuvant, and were placed in $10 \mathrm{ml}$ of lysis buffer (1\% Triton $\mathrm{X}-100,10 \mathrm{mM}$ Tris-Hcl, pH 7.6, $5 \mathrm{mM}$ EDTA, $50 \mathrm{mM} \mathrm{NaCl}, 30 \mathrm{mM}$ sodium pyrophosphate, $50 \mathrm{mM} \mathrm{NaF}, 100 \mu \mathrm{M} \mathrm{Na} \mathrm{VO}_{4}, 1 \mathrm{mM}$ PMSF, $0.5 \mu \mathrm{g} / \mathrm{ml}$ leupsin, $0.7 \mu \mathrm{g} / \mathrm{ml}$ pepstatin $\mathrm{A}, 0.1 \% \mathrm{BSA}, 0.1 \%$ azide). Synovial membrane specimens from patients with rheumatoid arthritis and osteoarthritis were also obtained and processed identically. The tissues were homogenized at the maximum setting for $\sim 3 \mathrm{~s}$ (Homogenizer; Brinkmann Instruments Co., Westbury, NY) and incubated on ice for $10 \mathrm{~min}$. Cellular debris was removed by centrifugation at $1,500 \mathrm{~g}$ at $4^{\circ} \mathrm{C}$ for $15 \mathrm{~min}$. The supernatants were transferred to $10 \mathrm{ml} \mathrm{Oak}$ Ridge tubes and centrifuged at $25,000 \mathrm{~g}$ at $4^{\circ} \mathrm{C}$ for $1 \mathrm{~h}$. The supernatants were used for analysis of cytoplasmic phosphotyrosine-containing proteins. Equal amounts of protein $(32 \mu \mathrm{g} /$ lane $)$ were separated on $10 \%$ Tris-tricine polyacrylamide 1-mm minigel (NOVEX, San Diego, $\mathrm{CA})$ and transferred to a nitrocellulose membrane $(0.2 \mu \mathrm{m}$; Schleicher \& Schuell, Inc., Keene, NH) using a semi-dry transfer unit (Millipore Corp., Bedford, MA) (27). The phosphotyrosine-containing proteins were detected on the membrane by a color reaction of substrate with alkaline phosphatase using a monoclonal antiphosphotyrosine Western blotting kit (Upstate Biotechnology Inc.). The blots were blocked with $3 \% \mathrm{wt} / \mathrm{vol}$ skim milk powder in PBS, pH 7.4, for $30 \mathrm{~min}$ and incubated with monoclonal anti-P-Tyr antibody $(1 \mu \mathrm{g} / \mathrm{ml}$; Upstate Biotechnology, Inc.) in blocking buffer overnight at $4^{\circ} \mathrm{C}$ with constant rocking. After rinsing with PBS the immunoblots were incubated with $0.5 \mu \mathrm{g} / \mathrm{ml}$ alkaline phosphatase-labeled goat anti-mouse IgG (Upstate Biotechnology, Inc.) for $1 \mathrm{~h}$ at room temperature. After immersing in $0.05 \% \mathrm{vol} / \mathrm{vol}$ Tween 20 in PBS pH 7.4 for 5 min and washing in PBS, the blots were incubated with alkaline phosphatase substrates (bromochloroindolyl phosphate and nitro blue tetrazolium in dimethylformamide) dissolved in developing buffer ( $100 \mathrm{mM} \mathrm{NaCl}, 5 \mathrm{mM} \mathrm{MgCl}$, $100 \mathrm{mM}$ Tris, $\mathrm{pH} 9.5$ ) until the bands were visible. The reaction was stopped with water rinses, the blots were air dried and photographed. Three controls, irrelevant isotype-matched immunoglobulin (mouse $\mathrm{IgG}_{2 \mathrm{~b}}$; Sigma Chemical Co.), affinity-negative fraction of anti-P-Tyr antibodies (Upstate Biotechnology, Inc.) adsorbed on P-Tyr-Sepharose 4B column, and the secondary antibody alone, were also performed to confirm the specificity of the P-Tyr antibody.

Statistical analysis. Analyses of data were performed using the Wilcoxon rank-sum test and Spearman's rank correlation (28).

\section{Results}

In situ P-Tyr immunostaining on synovial tissues from patients with $R A$ and $O A$. The IgG fraction of polyclonal anti-P-Tyr antibody or monoclonal anti-P-Tyr antibody was used to stain synovia from patients with RA and OA. As shown in a representative RA synovial tissue section, extensive and intense intra- cellular staining was observed within the synovial lining cell layer (Fig. $1 \mathrm{~A}$ ). Prominent P-Tyr staining was also observed in the sublining stromal fibroblast-like cells (Fig. $1 A$ ), vascular endothelial cells (Fig. $1 C$ ), and aggregated mononuclear cells (Fig. $1 D$ ). The intensity and localization of staining with polyclonal anti-P-Tyr antibody $(75 \mu \mathrm{g} / \mathrm{ml})$ was similar in all cases to the staining with monoclonal antibody at a concentration of $25 \mu \mathrm{g} / \mathrm{ml}$. Control staining was absent with nonspecific rabbit IgG (Fig. $1 B$ ), nonspecific mouse $\operatorname{IgG}_{1}-\kappa$ or P-Tyr monoclonal antibody that was adsorbed by preincubation with purified $\mathrm{P}$ Tyr. Synovial tissue sections from patients with $\mathrm{OA}$, in sharp contrast to the RA specimens, stained weakly in the lining cell layer, sublining vascular endothelial cells, and stromal fibroblast-like cells (Fig. $1 E$ ). In addition, "normal" synovial tissue sections from a subject undergoing arthroscopy for suspected traumatic injury did not stain (Fig. $1 F$ ).

The extent and intensity of staining with P-Tyr antibody was graded 0-4+ by a blinded observer on $18 \mathrm{RA}$ and $12 \mathrm{OA}$ synovial specimens. P-Tyr staining grades were much higher in synovia of RA patients (mean score $=2.2$ ) than in specimens of OA patients ( mean score $=0.5)(P<0.01$; Wilcoxon ranksum test). In addition, the extent and intensity of staining with P-Tyr antibody and the extent and intensity of mononuclear cell infiltration (assessed on $\mathrm{H}$ and $\mathrm{E}$-stained sections) in synovia of RA patients were highly correlated ( $r=0.63, P<0.01$; Spearman's rank correlation).

Correlation between P-Tyr, FGF-1, and PDGF-B immunostaining in $R A$ patients. As noted in the introduction, our group has recently reported high level expression of FGF-1 and PDGF-B-like factors in rheumatoid synovial tissues (11-13). The extent and intensity of FGF-1 and PDGF-B-like immunostaining in synovia of RA patients is also correlated with the extent and intensity of mononuclear cell infiltration, as well as c-myc and c- fos expression $(9,11,12)$. Several sections from the same tissue blocks were used to compare FGF-1, PDGF-B, and P-Tyr antigen expression. There was a significant correlation of P-Tyr expression with FGF-1 $(r=0.82, P<0.001)$ and with PDGF-B-like factor expression $(r=0.56, P<0.01)$. High grade intracellular staining with FGF-1 antibody was observed in the synovial lining cell layer, sublining stromal fibroblastlike cells, vascular endothelial cells, and inflammatory mononuclear cells (11). Immunoreactive PDGF-B expression was primarily noted in synovial lining cell layer and inflammatory mononuclear cells, but only equivocal or very weak immunostaining was noted in the vascular endothelial cells.

Double staining of synovial tissues from $R A$ patients with anti-FGF-1 and anti-P-Tyr antibodies or anti-PDGF-B and anti-P-Tyr antibodies. To localize and compare further the microanatomy of FGF-1, PDGF-B, and P-Tyr expression in the synovia of RA patients, we immunostained the same sections from RA synovia by a double antibody staining method. The

Figure 2. Double staining of the same synovial sections from RA patient with anti-FGF-1 and anti-P-Tyr antibodies or anti-PDGF-B and antiP-Tyr antibodies. Sections were stained with the first antibody (FGF-1 antibody or PDGF-B antibody) using the peroxidase method and with the second antibody (monoclonal anti-P-Tyr antibody) using the alkaline phosphatase method as described in Methods. Positive staining for peroxidase or alkaline phosphatase resulted in black or red deposits, respectively. Counterstaining was done with $0.5 \%$ light green SF. The magnification in all cases is 250 on the original photograph. $(A) \mathrm{RA}$ synovium stained with anti-FGF-1/mouse $\operatorname{IgG}_{1}$. (B) RA synovium stained with anti-PDGF-B/mouse $\mathrm{IgG}_{1}$. $(C)$ RA synovium stained with affinity-negative anti-FGF-1/monoclonal anti-P-Tyr. (D) RA synovium stained with mouse $\mathrm{IgG}_{2 b}$ /monoclonal anti-P-Tyr. $(E)$ RA synovium stained with anti-FGF-1/monoclonal anti-P-Tyr. $(F)$ RA synovium stained with anti-PDGF-B/monoclonal anti-P-Tyr. $(G)$ RA synovium stained with affinity-negative anti-FGF-1/mouse $\operatorname{IgG}_{1}$. $(H) \mathrm{RA}_{\text {synovium stained with }}$

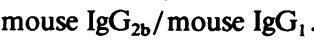


first antigen (FGF-1 or PDGF-B) was stained with peroxidase and second antigen (P-Tyr) was stained with alkaline phosphatase. Black or red deposits, respectively, represented positive staining. Intense black-red deposits were demonstrated in synovial lining cells and infiltrating mononuclear cells upon double staining with both anti-FGF-1 / anti-P-Tyr and anti-PDGF-B/ anti-P-Tyr (Fig. 2, $E$ and $F$ ). Synovial vascular endothelial cells showed black-red deposits with anti-FGF-1/anti-P-Tyr staining, but these cells showed only very light black deposits and intense red staining with anti-PDGF-B/anti-P-Tyr staining. Control staining with affinity-negative anti-FGF-1 / mouse

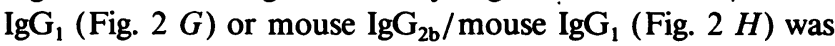
uniformly negative (light green staining). Staining with affin-

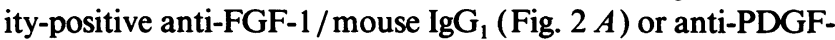
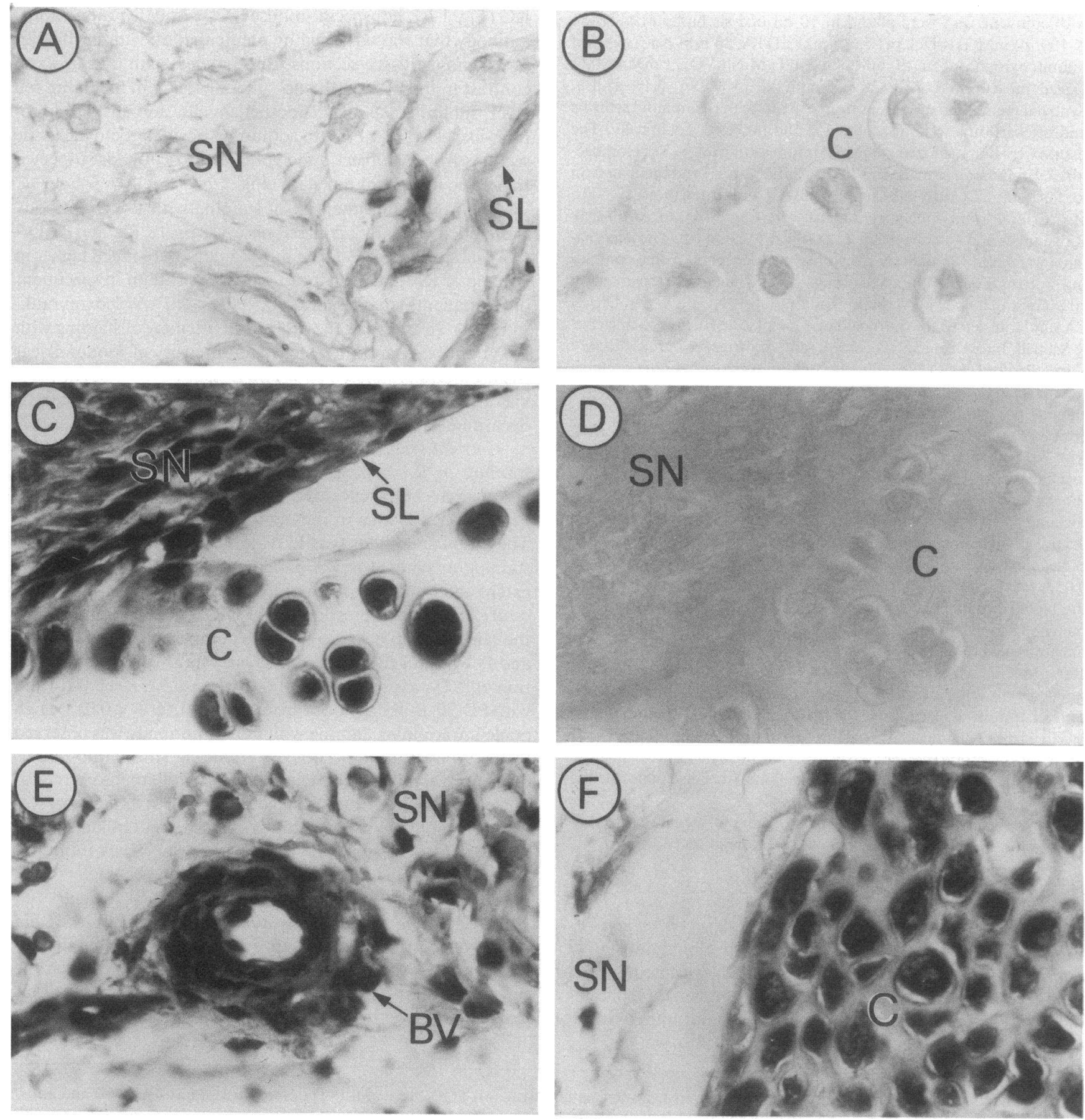

Figure 3. P-Tyr immunostaining in SCW-injected euthymic LEW/N rats. Sections $A-C, E$, and $F$ were stained with anti-P-Tyr monoclonal antibody $(25 \mu \mathrm{g} / \mathrm{ml})$ as described in Methods. Control staining with mouse $\mathrm{IgG}_{1}$ or monoclonal anti-P-Tyr that was preincubated with purified P-Tyr peptide was uniformly negative. $(A)$ and $(B)$ show representative hindfoot joints from noninjected euthymic LEW/N rats $(\times 250$ on original photographs). $(C),(E)$, and $(F)$ show representative hindfoot joints from SCW-injected euthymic LEW/N rats with chronic arthritis at day $28(\times 250$ on original photograph $)$. $(D)$ shows a hindfoot joint from the same section as $(C)$ stained with monoclonal anti-P-Tyr antibody that was preincubated with purified P-Tyr. The labels denote the cartilage $(C)$, synovial lining cell layer $(\mathrm{SL})$, sublining synovial tissue cells $(S N)$, and blood vessels $(B V)$. 


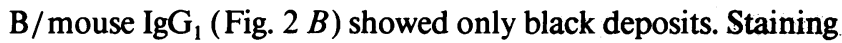
with affinity-negative anti-FGF-1/anti-P-Tyr (Fig. $2 C$ ) or

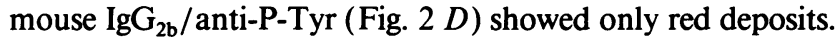

$P$-Tyr immunostaining in SCW-injected euthymic LEW/ $N$, athymic LEW.rnu/rnu, or euthymic F344/N rats. Immunostaining with monoclonal anti-P-Tyr, as well as the kinetics of its appearance in the synovium, was examined in SCW-injected euthymic LEW/N, athymic LEW.rnu/rnu, or euthymic F344/N rats. Both LEW/N and LEW.rnu/rnu rat strains, but not F344/ $\mathrm{N}$ rats, developed erythema and swelling of peripheral joints within $24 \mathrm{~h}$ of SCW administration. Histologically, this response is characterized by edema, fibrin deposition in the joint space and synovium, and cellular infiltration by granulocytes and macrophages. This rapid onset phase of disease typically reaches maximal severity at day 3 and then substantially decreases in severity over the next week (4).

P-Tyr staining was absent or equivocal in control rats not injected with SCW throughout the synovium (Fig. $3 A$ ), cartilage (Fig. $3 \mathrm{~B}$ ), and bone, but widespread P-Tyr expression, which reached maximal levels by day 3 after SCW injection (Table I), developed in both LEW/N and LEW.rnu/rnu rats. This enhanced expression paralleled the development of clinically observable joint inflammation. The synovial lining cell layer, synovial stromal fibroblast-like cells and blood vessels, perivascular inflammatory cells, cartilage chondrocytes, and osteoblasts within the bone matrix stained intensely (Table I). Sections from SCW-injected F344/N rats did not show enhanced expression of P-Tyr (Table I). Control staining with mouse $\mathrm{IgG}_{1}-\kappa$ or anti-P-Tyr antibody that was adsorbed by preincubation with purified P-Tyr was uniformly negative (Fig. $3 D$ ).

A highly destructive, thymic-derived lymphocyte-dependent phase of disease develops in euthymic LEW/N, but not athymic LEW.rnu/rnu nor F344/N, rats 14-28 d after injection (9). During this phase of disease, euthymic LEW/N, but not athymic LEW.rnu/rnu nor arthritis-resistant F344/N rats, expressed high grade P-Tyr throughout the involved joints including the synovial lining cell layer (Fig. $3 C$ ), sublining stromal cells (Fig. $3 C$ ), blood vessels (Fig. $3 E$ ), cartilage chondrocytes (Fig. $3 F$ ), subchondral bone cells (Fig. $3 F$ ), and bone matrix cells, as well as ligamentous and tendinous structures (Table I).
In addition to the staining of synovial connective tissues, cartilage, and bone, both SCW-injected euthymic LEW/N and athymic LEW.rnu/rnu rats with acute arthritis also exhibited P-Tyr expression in the hindlimb skin at days 1-4 (Table I). Cells in the epidermis and polymorphonuclear cells in the dermis surrounding the inflamed joints stained intensely. P-Tyr expression was demonstrated in the hindlimb skin at day 28 after SCW injection in euthymic LEW/N, but not athymic LEW.rnu/rnu, rats (Table I). Control euthymic LEW/N and athymic LEW.rnu/rnu, and control and SCW-injected F344/ $\mathrm{N}$ rats did not exhibit staining in skin (Table $\mathrm{I}$ ). Thus, persistent, high-level P-Tyr expression in the skin, like synovium, bone, and cartilage, was dependent on thymic-derived lymphocytes.

$P$-Tyr immunostaining in adjuvant-injected euthymic $L E W / N$, athymic $L E W . r n u / r n u$, and euthymic $F 344 / N$ rats. The injection of a suspension of heat-killed mycobacteria in mineral oil induces chronic, destructive peripheral arthritis in LEW/N rats, but not athymic LEW.rnu/rnu rats. Clinically apparent disease appears on or about day 10 after adjuvant injection $(10,22) . \mathrm{F} 344 / \mathrm{N}$ female rats develop equivocal or very low grade clinically-apparent arthritis (26).

To determine when P-Tyr expression was first detected in AA, rats were killed at 2-d intervals after adjuvant injection and examined immunohistochemically with monoclonal antiP-Tyr antibody. Basal expression of P-Tyr, as noted above, was absent or equivocal. Although clinically observable inflammation was absent at days 2-4 after adjuvant injection, we detected low grade $\mathrm{P}$-Tyr expression on the synovial lining cell layer (Fig. $4 A$ ), synovial stromal fibroblast-like cells (Fig. 4 $A$ ), blood vessels (Fig. $4 A$ ), cartilage chondrocytes (Fig. $4 B$ ), subchondral bone (Fig. $4 B$ ), bone marrow cells as well as skin epidermis of both LEW/N and LEW.rnu/rnu rats (Table II). By days 10-18 after adjuvant injection, P-Tyr was intensely expressed in synovial lining cell layer, synovial stromal fibroblast-like cells (Fig. 4, $C$ and $D$ ), inflammatory mononuclear cells (Fig. $4 C$ ), blood vessels, cartilage chondrocytes, subchondral bone (Fig. $4 D$ ), bone marrow cells (Fig. $4 D$ ) as well as skin epidermis of the hindlimbs in euthymic LEW/N rats. By days 10-18, immunostaining in LEW.rnu/rnu rats, however, decreased to levels similar to control animals ( Table II). Upregulated P-Tyr expression was not noted in arthritis-resistant

Table I. P-Tyr Expression in SCW-injected Rats*

\begin{tabular}{|c|c|c|c|c|c|c|c|c|c|}
\hline & \multicolumn{3}{|c|}{ Day 0} & \multicolumn{3}{|c|}{ Day 3} & \multicolumn{3}{|c|}{ Day 28} \\
\hline & LEW/N & $\begin{array}{l}\text { LEW. } \\
\text { mu/rnu }\end{array}$ & $\mathrm{F} 344 / \mathrm{N}$ & LEW/N & $\begin{array}{l}\text { LEW. } \\
\text { rnu/rnu }\end{array}$ & F344/N & LEW/N & $\begin{array}{l}\text { LEW. } \\
\text { rnu/rnu }\end{array}$ & $\mathrm{F} 344 / \mathrm{N}$ \\
\hline $\begin{array}{l}\text { Skin epidermis } \\
\text { Synovium }\end{array}$ & $0-1+$ & $0-1+$ & $0-1+$ & $3-4+$ & $2-3+$ & $1-2+$ & $3-4+$ & $0-1+$ & $0-1+$ \\
\hline Lining cell layer & $0-1+$ & $0-1+$ & $0-1+$ & $3-4+$ & $2-3+$ & $1-2+$ & $3-4+$ & $0-1+$ & $0-1+$ \\
\hline Vascular endothelium & $0-1+$ & $0-1+$ & $0-1+$ & $2-3+$ & $2+$ & $0-1+$ & $2-3+$ & $0-1+$ & $0-1+$ \\
\hline Mononuclear inflammatory cells & NP & NP & NP & $3-4+$ & $2-3+$ & NP & $3-4+$ & NP & NP \\
\hline Stromal fibroblast-like cells & $0-1+$ & $0-1+$ & $0-1+$ & $4+$ & $3+$ & $0-1+$ & $3-4+$ & $0-1+$ & $0-1+$ \\
\hline Cartilage chondrocytes & $0-1+$ & $0-1+$ & $0-1+$ & $3-4+$ & $2-3+$ & $1-2+$ & $2-3+$ & $0- \pm$ & $1-2+$ \\
\hline Subchondral bone & $0-1+$ & $0-1+$ & $0-1+$ & $1+$ & $1+$ & $0-1+$ & $2-3+$ & $0- \pm$ & $0-1+$ \\
\hline Bone marrow & $0-1+$ & $0-1+$ & $0-1+$ & $3+$ & $2-3+$ & $1+$ & $3-4+$ & $0-1+$ & $1+$ \\
\hline
\end{tabular}

* Graded $0-4+$ on coded slides by a blinded observer. 0 = no staining, 4 = maximal intensity. NP, not present. 

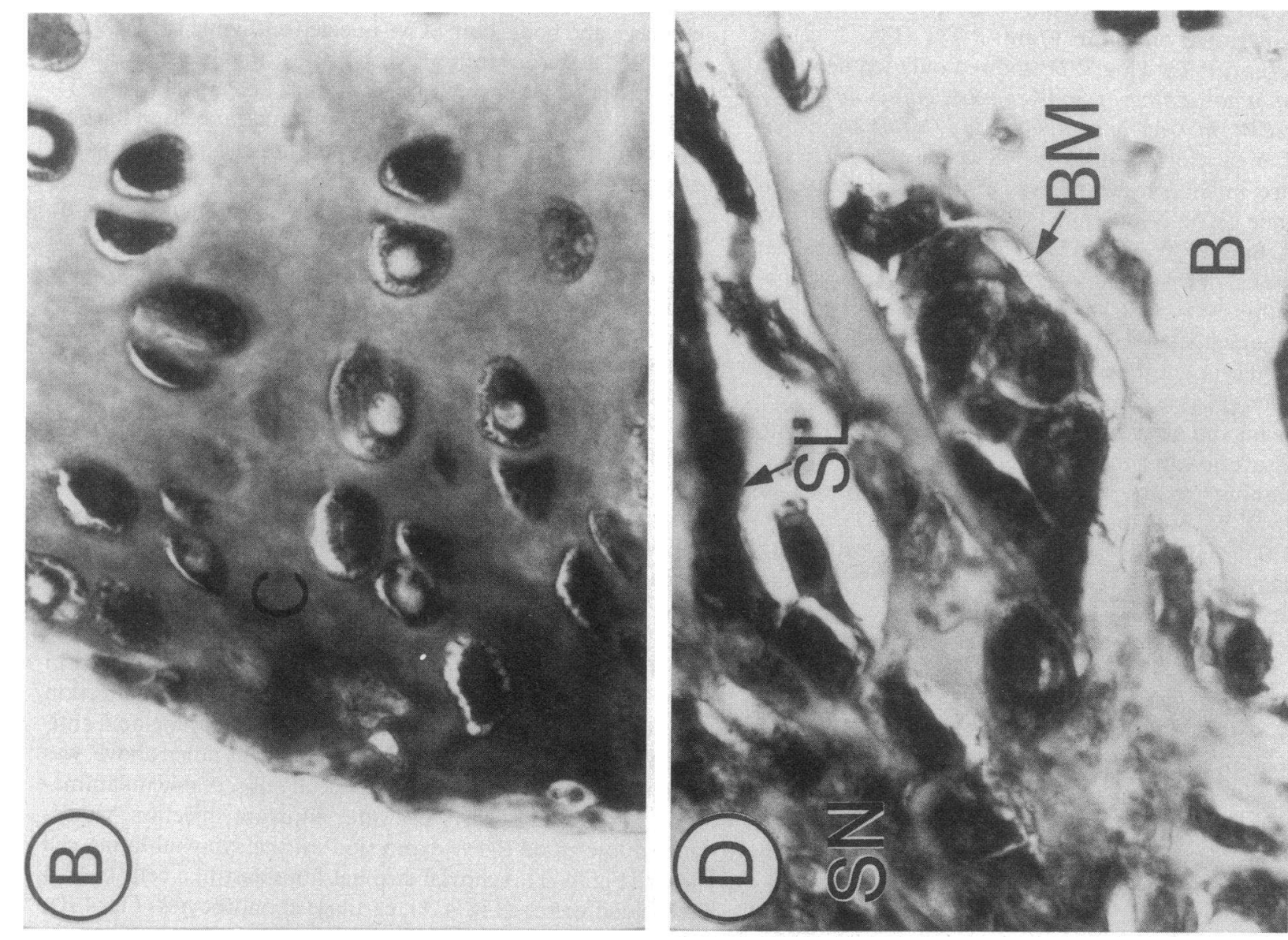

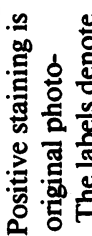

흥 起诘 형

중

등 क्ष g

흘

of o뭉

牙

त्र त्]

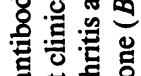

ส]

要

흥

능

要

两

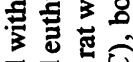

妨


s.

政

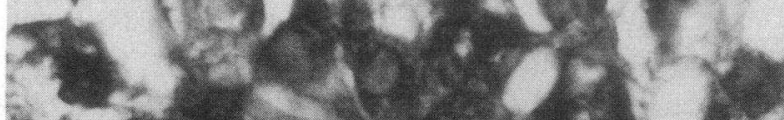

㝵

政

\%
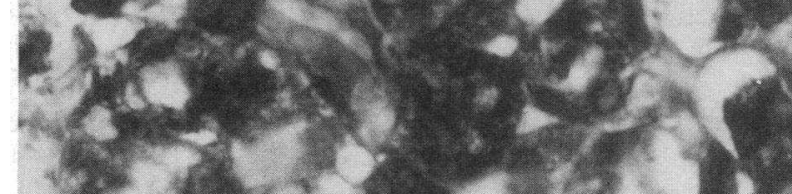

窟

z

3응
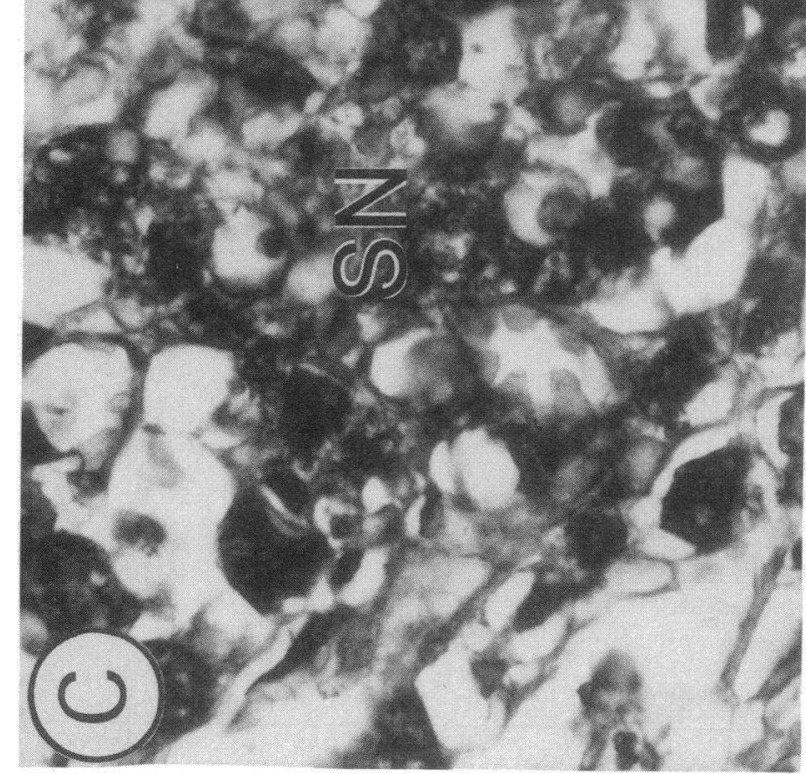

굴

政

.

造要

政

政

要

蛋梂

들

可

क्ष

客要

要

5 告

i

$+8$

论

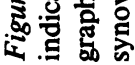


F344/N rats at any timepoint ( Table II). Control staining with monoclonal anti-P-Tyr antibody adsorbed by preincubation with purified P-Tyr or normal mouse $\mathrm{IgG}_{1^{-}} \kappa$ was uniformly negative in all cases.

$P$-Tyr immunostaining in adjuvant-injected $L E W / N$ rats treated with glucocorticoids. As shown in our previous study (26) and Fig. 5 and Table III, treatment of adjuvant-injected $\mathrm{LEW} / \mathrm{N}$ rats with dexamethasone in the physiologically relevant doses $(0.02 \mu \mathrm{g} / \mathrm{g}$ body $\mathrm{wt})$ strikingly suppresses clinical arthritis. It also suppressed P-Tyr expression in synovial lining cell layer (Fig. 5, $A$ and $B$ ), synovial stromal fibroblast-like cells (Fig. 5, $A$ and $B$ ), vascular endothelial cells, cartilage chondrocytes (Fig. 5, $C$ and $D$ ), subchondral bone cells, bone marrow cells as well as skin epidermis (Fig. 5, $E$ and $F$ ). Control staining with monoclonal anti-P-Tyr antibody preincubated with purified $\mathrm{P}$-Tyr or mouse $\mathrm{IgG}_{1^{-}} \kappa$ was uniformly negative.

Immunoblot analysis of phosphotyrosine-labeled proteins in synovia from $R A$ and $O A$ patients and rats with $S C W$-and adjuvant-arthritis. To estimate the sizes and the number of proteins that were tyrosine phosphorylated in the inflamed synovia, we extracted cytoplasmic proteins from synovia from RA and OA patients. We also extracted cytoplasmic proteins from synovial tissues of noninjected control LEW/N rats, and from LEW/N rats $3 \mathrm{~d}$ after SCW injection and $18 \mathrm{~d}$ after adjuvant injection. Immunoblot analysis of these synovial extracts with monoclonal anti-P-Tyr antibody showed markedly enhanced expression of a 45-kD tyrosine phosphoprotein in the RA patients versus OA (Fig. $6 A$ ) and the arthritic versus control rats (Fig. $6 \mathrm{~B}$ ).

Additional tyrosine phosphoproteins in higher molecular weight range ( $>45 \mathrm{kD}$ ) were also evident in the extracts of the synovia from rats with arthritis and some of the RA extracts. These bands were not detectable in the synovial extracts from the control rats or OA patients (Fig. 6, $A$ and $B$ ). Control immunoblot analysis of the same samples with the secondary antibody alone, a nonspecific isotypic immunoglobulin ( mouse $I g G_{2 b}$ ) or the original primary antibody adsorbed on a P-Tyr column confirmed the specificity of the $45-\mathrm{kD}$ band and several higher molecular weight bands (not shown).

\section{Discussion}

RA patients and the rat experimental arthritis models, SCWand adjuvant-induced arthritis, are characterized by massive hypertrophy and hyperplasia of the normally thin, delicate synovial membrane, resulting primarily from proliferation of stromal fibroblast-like cells and new blood vessels (1-4). These cells are the predominant synovial cell populations at sites of cartilage resorption and bone erosion. We have suggested that this invasive behavior resembles a localized nonmetastatic neoplasm $(1,4-13)$. For example, in vivo the highly proliferative and invasive tissue expresses high levels of protooncogenes such as c- fos (11) and c-myc (9), and metalloproteinases such as transin/stromelysin $(9,10)$. Moreover, when stimulated in vitro with growth factors such as PDGF or FGF, freshly explanted synovial fibroblast-like cells from rheumatoid and SCW arthritic joints (a) proliferate rapidly in vitro (6-8); $(b)$ do not undergo contact inhibition, but rather form foci $(8) ;(c)$ grow under anchorage-independent conditions $(6,8)$; and $(d)$ form short-lived tumor-like nodules when implanted in nude, athymic mice $(6,13)$. These data suggest that synovial fibroblasts may exhibit properties generally associated with invasive tumor cells as a consequence of stimulation by polypeptide factors like FGF-1 and PDGF probably acting in conjunction with many other regulatory polypeptides and mediators (29-32).

Consistent with this hypothesis, we have detected high levels of FGF-1 (11) in the synovial tissues from RA, but not OA patients. We have also detected high levels of FGF-1 in both SCW and adjuvant arthritic LEW/N rats, but not relatively arthritis-resistant F344/N rats. FGF-1 is a potent angiogenic factor and angiogenesis is a prominent feature of RA and arthritic rat models (11-13). High levels of PDGF-B-like polypeptides, PDGF-A-like polypeptides and their receptors have also been detected in RA, but not OA synovial sections $(7,12,13)$.

Numerous in vitro studies have shown that the interaction of FGF-1 and PDGF with their receptors stimulates tyrosine kinase activities (14-17). The receptors for FGF-1 and PDGF are part of the family of growth factor receptors that have in-

Table II. P-Tyr Expression in Adjuvant-injected Rats*

\begin{tabular}{|c|c|c|c|c|c|c|c|c|c|c|c|c|c|c|c|}
\hline & \multicolumn{3}{|c|}{ Day 0} & \multicolumn{3}{|c|}{ Day 2} & \multicolumn{3}{|c|}{ Day 4} & \multicolumn{3}{|c|}{ Day 10} & \multicolumn{3}{|c|}{ Day 18} \\
\hline & LEW/N & $\begin{array}{l}\text { LEW. } \\
\mathrm{rnu} / \mathrm{rnu}\end{array}$ & F344/N & LEW/N & $\begin{array}{l}\text { LEW. } \\
\mathrm{rnu} / \mathbf{r n u}\end{array}$ & F344/N & LEW/N & $\begin{array}{l}\text { LEW. } \\
\mathrm{rnu} / \mathbf{m u}\end{array}$ & F344/N & LEW/N & $\begin{array}{l}\text { LEW. } \\
\text { rnu/rnu }\end{array}$ & F344/N & LEW/N & $\begin{array}{c}\text { LEW. } \\
\text { rnu/rnu }\end{array}$ & F344/N \\
\hline Skin epidermis & $0-1+$ & $0-1+$ & $0-1+$ & $2+$ & ND & $0-1+$ & $3+$ & $3+$ & $0-1+$ & $3+$ & $0-1+$ & $0-1+$ & $4+$ & $0-1+$ & $0-1+$ \\
\hline \multicolumn{16}{|l|}{ Synovium } \\
\hline Lining cell layer & $0-1+$ & $0-1+$ & $0-1+$ & $1+$ & ND & $0-1+$ & $3+$ & $2+$ & $0-1+$ & $3+$ & $0-1+$ & $0- \pm$ & $4+$ & 0 & $0-1+$ \\
\hline Vascular endothelium & $0-1+$ & $0-1+$ & $0-1+$ & $1+$ & ND & $0-1+$ & $3+$ & $2+$ & $0- \pm$ & $3+$ & $0-1+$ & $0-1+$ & $4+$ & $0-1+$ & $0-1+$ \\
\hline Mononuclear & & & & & & & & & & & & & & & \\
\hline inflammatory cells & NP & NP & NP & NP & ND & NP & NP & NP & NP & $0-2+$ & NP & NP & $4+$ & NP & NP \\
\hline \multicolumn{16}{|l|}{ Stromal fibroblast-like } \\
\hline cells & $0-1+$ & $0-1+$ & $0-1+$ & $1+$ & ND & $0-1+$ & $3+$ & $2+$ & $0- \pm$ & $3-4+$ & $1+$ & $0-1+$ & $4+$ & $0-1+$ & $0-1+$ \\
\hline Cartilage chondrocytes & $0-1+$ & $0-1+$ & $0-1+$ & $1+$ & ND & $0-1+$ & $3+$ & $2-3+$ & $0- \pm$ & $3+$ & $1+$ & $0-1+$ & $4+$ & $0-1+$ & $0-1+$ \\
\hline Subchondral bone & $0-1+$ & $0-1+$ & $0-1+$ & $1+$ & ND & $0-1+$ & $2+$ & $3+$ & $0- \pm$ & $2+$ & $0-1+$ & $0- \pm$ & $3+$ & $0-1+$ & $0- \pm$ \\
\hline Bone marrow & $0-1+$ & $0-1+$ & $0-1+$ & $0-1+$ & ND & $0-1+$ & $3+$ & $3+$ & $0-1+$ & $2-3+$ & $1+$ & $0-1+$ & $4+$ & $0-1+$ & $0-1+$ \\
\hline
\end{tabular}

* Graded 0-4+ on coded slides by a blinded observer. 0 = no staining, 4 = maximal intensity. ND, not done; NP, not present. 



Figure 5. P-Tyr immunostaining in adjuvant-injected LEW/N rats treated with glucocorticoids. Treatment of adjuvant-injected LEW/N rats with dexamethasone in a physiologically relevant dose $(0.02 \mu \mathrm{g} / \mathrm{g}$ of the body wt $)$ strikingly suppressed P-Tyr expression. Sections were stained with anti-P-Tyr monoclonal antibody $(25 \mu \mathrm{g} / \mathrm{ml})$ as described in Methods. $(A)$ and $(C)$ show a representative hindfoot joint from an adjuvantinjected LEW/N rats at day 12 treated with vehicle alone $(\times 250$ on original photograph $) .(B)$ and $(D)$ show a representative hindfoot joint from adjuvant-injected LEW/N rats at day 12 treated with dexamethasone $(\times 250$ on original photograph $)$. $(E)$ and $(F)$ show representative hindfoot skin sections from an adjuvant-injected LEW/N rat treated with vehicle alone or dexamethasone, respectively $(\times 250$ on original photograph). The labels denote synovial lining cell layer $(S L)$, sublining synovial tissue cells $(S N)$, cartilage $(C)$, bone $(B)$, and skin epidermis $(S E)$.

trinsic tyrosine kinase activity. These include, in addition to FGF-1 and PDGF, the receptors for EGF (33), insulin (34), insulin-like growth factor-I ( 35 ) and colony-stimulating factorI (36). We proposed that FGF-1 and PDGF-stimulated tyrosine phosphorylation may play a role in vivo in the generation of invasive synovial connective tissue in rheumatoid arthritis and related conditions $(15,16)$. The data presented in this manuscript provide evidence in support of this hypothesis.
First, we observed that P-Tyr immunostaining was more extensive and intense in the synovia of RA patients than OA and normal human subjects and correlated with the extent and intensity of synovial mononuclear cell infiltration. There was a significant correlation in RA synovia between FGF-1, PDGF$\mathrm{B}$ and P-Tyr immunostaining, and double antibody staining methods showed extensive coexpression of FGF-1 and P-Tyr, or PDGF-B and P-Tyr in the synovial lining cells and inflam- 
Table III. P-Tyr Expression in Adjuvant-injected LEW/N Rats Treated with Glucocorticoids*

\begin{tabular}{|c|c|c|c|c|c|c|c|}
\hline & \multirow{2}{*}{ Day 0} & \multicolumn{2}{|c|}{ Day 4} & \multicolumn{2}{|c|}{ Day 8} & \multicolumn{2}{|r|}{ Day 12} \\
\hline & & \multicolumn{2}{|c|}{ Treatment with } & \multicolumn{2}{|c|}{ Treatment with } & \multicolumn{2}{|c|}{ Treatment with } \\
\hline & No treatment & Vehicle & Glucocorticoids & Vehicle & Glucocorticoids & Vehicle & Glucocorticoids \\
\hline Skin epidermis & $0-1+$ & $1-2+$ & $\pm-1+$ & $2-3+$ & $0-1+$ & $3-4+$ & $0-1+$ \\
\hline \multicolumn{8}{|l|}{ Synovium } \\
\hline Lining cell layer & $0- \pm$ & $1-2+$ & $0-1+$ & $2-3+$ & $0-1+$ & $3+$ & $0- \pm$ \\
\hline Vascular endothelium & $0-1+$ & $2+$ & $0-1+$ & $2+$ & $0-1+$ & $2-3+$ & $0- \pm$ \\
\hline Mononuclear inflammatory cells & $\mathrm{NP}^{\ddagger}$ & NP & NP & NP & NP & $3+$ & NP \\
\hline Stromal fibroblast-like cells & $0- \pm$ & $2+$ & $0-1+$ & $2-3+$ & \pm & $3+$ & $0- \pm$ \\
\hline Cartilage chondrocytes & $0-1+$ & $2+$ & $0- \pm$ & $2-3+$ & $\pm-1+$ & $3+$ & $0-1+$ \\
\hline Subchondral bone & $0-1+$ & $2+$ & $0-1+$ & $2-3+$ & $\pm-1+$ & $2-3+$ & $\pm-1+$ \\
\hline Bone marrow & $\pm-1+$ & $1-2+$ & $\pm-1+$ & $3+$ & $\pm-1+$ & $3+$ & $\pm-1+$ \\
\hline
\end{tabular}

* Graded 0-4+ on coded sections by a blinded observer. $0=$ no staining, $4+=$ maximal intensity. See Methods for further details. NP, not present.

matory mononuclear cells in RA patients. Anti-PDGF-B did not, however, stain vascular endothelial cells, as we reported previously $(12,13)$. These data, thus, suggest that FGF-1 and PDGF-B-like factors are upregulated in RA synovia and may activate tyrosine kinase activities. This suggestion was also supported by our studies in SCW and adjuvant-injected arthritic LEW/N rats. High levels of immunohistochemical staining with P-Tyr antibody were detected in the joints of the arthritic but not the control rats. P-Tyr expression was detected at day 3 after SCW injection in athymic LEW.rnu/rnu rats with acute arthritis, and at day 4 after adjuvant injection in athymic rats without clinically apparent arthritis. It was not sustained. These observations demonstrate that persistent expression of

A

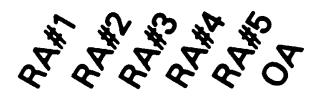

B
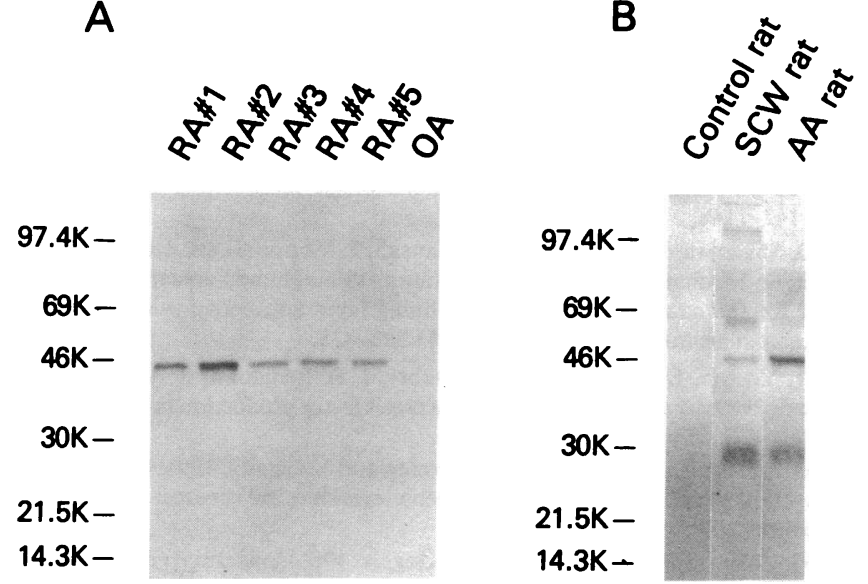

Figure 6. Immunoblot analysis of phosphotyrosine-containing proteins in patients with RA and OA, or LEW/N rats with SCW- and adjuvant-arthritis. $(A)$ Lanes $1-5$, extracts of synovia from patients with rheumatoid arthritis $(R A)$; lane 6 , extract of synovia from a patient with osteoarthritis. Note particularly the $45-\mathrm{kD}$ specific protein band in the RA extracts. $(B)$ Lane 1 , extract of control synovial tissue that was obtained from ankle joints of healthy, nonarthritic, LEW/N rats; lane 2, extract of synovial tissue from a rat with SCW arthritis at day 3; lane 3, extract of synovial tissue from a rat with adjuvant arthritis at day 18 . Note the presence of specific phosphotyrosine-containing proteins in the synovial extracts from the arthritic rats that are not present in the extracts of normal synovia. Size markers are also indicated.
P-Tyr, as well as chronic arthritis, requires an intact T lymphocyte-dependent immune system.

Moreover, staining with anti-P-Tyr antibody was absent or questionable in relatively arthritis-resistant $\mathrm{F} 344 / \mathrm{N}$ rats after the injection with SCW or adjuvant. Recent data have suggested that arthritis resistance in F344/N rats may be associated with their robust hypothalamic-pituitary-adrenal axis (HPA) responses to inflammatory stimuli (37-42). F344/N female rats show a rapid increase in plasma ACTH and corticosteroid levels in response to SCW and many other stimuli, as well as increased hypothalamic release and synthesis of corticotropin releasing hormone. In sharp contrast, the HPA response is profoundly blunted and delayed in LEW/N rats. Consistent with this view, administration of physiologically relevant doses of corticosteroids to LEW / $\mathrm{N}$ rats suppressed adjuvant arthritis and P-Tyr expression. These data, thus, show that the generation P-Tyr in vivo is strain dependent and susceptible to downregulation by glucocorticoids.

Finally, immunoblot analysis of control, 3-d SCW, and 18d AA rats and RA synovia detected the enhanced levels of expression of a 45-kD phosphotyrosine-containing polypeptide. Multiple additional immunostained bands were also detected in cytoplasmic extracts of synovial tissues, particularly in blots of LEW/N rats $3 \mathrm{~d}$ after injection with SCW and $18 \mathrm{~d}$ after adjuvant injection.

Receptors for FGF-1 and PDGF with molecular masses of 110 and $150 \mathrm{kD}(14,16)$, and $180 \mathrm{kD}(15)$, respectively, are present on a wide variety of cells. A common mechanism through which these growth factors stimulate cell proliferation is the induction of tyrosine kinase activity. FGF-1 stimulates tyrosine phosphorylation of 150,130 , and $90-\mathrm{kD}$ proteins in NIH 3 T3 cells (25) and 145-210 and $90-\mathrm{kD}$ proteins in Swiss $3 T 3$ cells (43). PDGF stimulates tyrosine phosphorylation of $300-200,115,72,54,45$, and $35-k D$ proteins in human fibroblasts (24). Indeed, autophosphorylation of the PDGF receptor is important both for its subsequent interactions with substrates and for induction of DNA synthesis $(15,44-46)$. Moreover, intracellular tyrosine kinases such as Src, Fyn, and Yes have been reported to associate with the $\beta$-PDGF receptor, and PDGF may serve to amplify the tyrosine kinase activity of these proteins (47-49). Our immunostaining and immunoblot data are, thus, consistent with a role for FGF-1 and PDGF at the inflammatory site. Furthermore, our data suggest that the 
interaction of growth factors with their receptors may regulate the appearance of increased phosphotyrosine-containing proteins in synovial cells which may serve as one of the signals responsible for the highly destructive tumor-like behavior of synovial connective tissues in inflammatory arthritis. Our data, however, do not exclude a role for other regulatory factors on the induction of tyrosine phosphorylation.

\section{Acknowledgments}

We thank Drs. Hereward Cattell, Patrick Caufield, Anthony Unger, Edward Bieber, Lewis Ottenritter, and Randall Lewis for their help in obtaining synovial tissues. We thank Dr. John P. Case for assistance with the adjuvant arthritis studies, and gratefully acknowledge Drs. Joseph M. Cash and Hongbin Zha for their suggestions and critical review of the manuscript.

This work was supported in part by a Public Health Service grant (HL-32348) to Dr. Maciag from the National Institutes of Health.

\section{References}

1. Harris, E. D., Jr. 1976. Recent insights into the pathogenesis of the proliferative lesion in rheumatoid arthritis. Arthritis Rheum. 19:68-72.

2. Bromley, M., and D. E. Woolley. 1984. Histopathology of the rheumatoid lesion: identification of cell types at sites of cartilage erosion. Arthritis Rheum. 27:857-863.

3. Bromley, M., and D. E. Woolley. 1984. Chondroclasts and osteoclasts at subchondral sites of erosion in the rheumatoid joint. Arthritis Rheum. 27:968975.

4. Wilder, R. L., J. B. Allen, and C. Hansen. 1987. Thymus-dependent and independent regulation of Ia antigen expression in situ by cells in the synovium of rats with streptococcal cell wall-induced arthritis: differences in site and intensity of expression in euthymic, athymic, and cyclosporin A-treated LEW and F344 rats. J. Clin. Invest. 79:1160-1171.

5. Haraoui, B., R. L. Wilder, J. B. Allen, M. B. Sporn, R. K. Helfgott, and C. E. Brinckerhoff. 1985. Dose-dependent suppression by the synthetic retinoid, 4-hydroxyphenyl retinamide, of streptococcal cell wall-induced arthritis in rats. Int. J. Immunopharmacol. 7:903-916.

6. Yocum, D. E., R. Lafyatis, E. F. Remmers, H. R. Schumacher, and R. L. Wilder. 1988. Hyperplastic synoviocytes from rats with streptococcal cell wall-induced arthritis exhibit a transformed phenotype that is thymic-dependent and retinoid inhibitable. Am. J. Pathol. 132:38-42.

7. Remmers, E. F., R. Lafyatis, G. K. Kumkumian, J. P. Case, A. B. Roberts, M. B. Sporn, and R. L. Wilder. 1990. Cytokines and growth regulation of synoviocytes from patients with rheumatoid arthritis and rats with streptococcal cell wall arthritis. Growth Factors. 2:179-188.

8. Lafyatis, R., E. F. Remmers, A. B. Roberts, D. E. Yocum, M. B. Sporn, and R. L. Wilder. 1989. Anchorage-independent growth of synoviocytes from arthritic and normal joints: stimulation by exogenous platelet-derived growth factor and inhibition by transforming growth factor-beta and retinoids. J. Clin. Invest. 83:1267-1276.

9. Case, J. P., R. Lafyatis, E. F. Remmers, G. K. Kumkumian, and R. L. Wilder. 1989. Transin/stromelysin expression in rheumatoid synovium: a transformation-associated metalloproteinase secreted by phenotypically invasive synoviocytes. Am. J. Pathol. 135:1055-1064.

10. Case, J. P., H. Sano, R. Lafyatis, E. F. Remmers, G. K. Kumkumian, and R. L. Wilder. 1989. Transin/stromelysin expression in the synovium of rats with experimental erosive arthritis: In situ localization and kinetics of expression of the transformation-associated metalloproteinase in euthymic and athymic Lewis rats. J. Clin. Invest. 84:1731-1740.

11. Sano, H., R. Forough, J. A. M. Maier, J. P. Case, A. Jackson, K. Engleka, T. Maciag, and R. L. Wilder. 1990. Detection of high levels of heparin-binding growth factor-1 (acidic fibroblast growth factor) in inflammatory arthritic joints. J. Cell Biol. 110:1417-1426.

12. Remmers, E. F., H. Sano, R. Lafyatis, J. P. Case, G. K. Kumkumian, T. Hla, T. Maciag, and R. L. Wilder. 1991. Production of platelet derived growth factor B chain (PDGF-B/c-sis) mRNA and immunoreactive PDGF-B-like polypeptide by rheumatoid synovium: coexpression with heparin binding acidic fibroblast growth factor-1. J. Rheumatol. 18:7-13.

13. Remmers, E. F., H. Sano, and R. L. Wilder. 1991. Platelet-derived growth factors and heparin-binding (fibroblast) growth factors in the synovial tissue pathology of rheumatoid arthritis. Semin. Arthritis Rheum. 21:191-199.

14. Burgess, W. H., and T. Maciag. 1989. The heparin-binding (fibroblast) growth factor family of proteins. Annu. Rev. Biochem. 58:575-606.
15. Williams, L. T. 1989. Signal transduction by the platelet-derived growth factor receptor. Science (Wash. DC). 243:1564-1570.

16. Friesel, R., W. H. Burgess, and T. Maciag. 1989. Heparin-binding growth factor 1 stimulates tyrosine phosphorylation in NIH 3T3 Cells. Mol. Cell. Biol. 9:1857-1865.

17. Ullrich, A., and J. Schlessinger. 1990. Signal transduction by receptors with tyrosine kinase activity. Cell. 61:203-212.

18. Arnett, F. C., S. M. Edworthy, D. A. Bloch, D. J. McShane, J. F. Fries, N. S. Cooper, L. A. Healey, S. R. Kaplan, M. H. Liang, H. S. Luthra, et al. 1988. The American Rheumatism Association 1987 revised criteria for the classification of rheumatoid arthritis. Arthritis Rheum. 31:315-324.

19. Altman, R., E. Ash, D. Bloch, G. Bole, D. Borenstein, K. Brandt, W. Christy, T. D. Cooke, R. Greenwald, M. Hochberg, et al. 1986. Development of criteria for the classification and reporting of osteoarthritis. Arthritis Rheum. 29:1039-1049.

20. Wilder, R. L., G. B. Calandra, A. J. Garvin, K. D. Wright, and C. T. Hansen. 1982. Strain and sex variation in the susceptibility to streptococcal cell wall-induced polyarthritis in the rat. Arthritis Rheum. 25:1064-1072.

21. Wilder, R. L. 1988. Streptococcal cell wall-induced polyarthritis in rats. In CRC Handbook of the Rheumatic Diseases. Vol. I. R. A. Greenwald and H. S. Diamond, editors. CRC Press, Inc., Boca Raton, FL. 33-40.

22. Case, J. P., H. Lorberboum-Galski, R. Lafyatis, D. FitzGerald, R. L. Wilder, and I. Pastan. 1989. Chimeric cytotoxin IL2-PE40 delays and mitigates adjuvant-induced arthritis in rats. Proc. Natl. Acad. Sci. USA. 86:287-291.

23. Lorberboum-Galski, H., R. Lafyatis, J. P. Case, D. FitzGerald, R. L. Wilder, and I. Pastan. 1989. Administration of IL-2-PE40 via osmotic pumps prevents adjuvant-induced arthritis in rats: improved therapeutic index of IL-2PE40 administered by continuous infusion. Int. J. Immunopharmacol. 13:305315.

24. Ek, B., and C.-H. Heldin. 1984. Use of an antiserum against phosphotyrosine for the identification of phosphorylated components in human fibroblasts stimulated by platelet-derived growth factor. J. Biol. Chem. 259:11145-11152.

25. Uhn, R. D., M. R. Posner, S. I. Rayter, J. G. Foulkes, and A. R. Frackelton, Jr. 1987. Cell lines and peripheral blood leukocytes derived from individuals with chronic myelogenous leukemia display virtually identical proteins phosphorylated on tyrosine residues. Proc. Natl. Acad. Sci. USA. 84:4408-4412.

26. Sano, H., T. Hla, J. A. M. Maier, L. J. Crofford, J. P. Case, T. Maciag, and R. L. Wilder. 1992. In vivo cyclooxygenase expression in synovial tissues of patients with rheumatoid arthritis and osteoarthritis and rats with adjuvant and streptococcal cell wall arthritis. J. Clin. Invest. 89:97-108.

27. Towbin, H., T. Staehelin, and J. Gordon. 1979. Electrophoretic transfer of proteins from polyacrylamide gels to nitrocellulose sheets: procedure and some applications. Proc. Natl. Acad. Sci. USA. 76:4350-4354.

28. Remington, R. D., and M. A. Shork. 1985. Statistics with Applications to the Biological and Health Sciences. Prentice-Hall, Inc., Englewood Cliffs, NJ. 415 pp.

29. Lafyatis, R., N. L. Thompson, E. F. Remmers, K. C. Flanders, N. S. Roche, S.-J. Kim, J. P. Case, M. B. Sporn, A. B. Roberts, and R. L. Wilder. 1989. Transforming growth factor-beta production by synovial tissues from rheumatoid patients and streptococcal cell wall arthritic rats: studies on secretion by synovial fibroblast-like cells and immunohistologic localization. J. Immunol. 143:1142-1148.

30. Shiozawa, S., K. Shiozawa, Y. Tanaka, I. Morimoto, M. Uchihashi, T. Fujita, K. Hirohata, Y. Hirata, and S. Imura. 1989. Human epidermal growth factor for the stratification of synovial lining layer and neovascularization in rheumatoid arthritis. Ann. Rheum. Dis. 48:820-828.

31. Yocum, D. E., L. Esparza, S. Dubry, J. B. Benjamin, R. Volz, and P. Scuderi. 1989. Characteristics of tumor necrosis factor production in rheumatoid arthritis. Cell. Immunol. 122:131-145.

32. Bucala, R., C. Ritchlin, R. Winchester, and A. Cerami. 1991. Constitutive production of inflammatory and mitogenic cytokines by rheumatoid synovial fibroblasts. J. Exp. Med. 173:569-574.

33. Cohen, S., G. Carpenter, and L. King, Jr. 1980. Epidermal growth factorreceptor-protein kinase interactions: copurification of receptor and epidermal growth factor-enhanced phosphorylation activity. J. Biol. Chem. 255:48344842.

34. Kasuga, M., Y. Zick, D. L. Blithe, M. Crettaz, and C. R. Kahn. 1982. Insulin stimulates phosphorylation of the insulin receptor in a cell free system. Nature (Lond.). 298:667-669.

35. Jacobs, S., F. C. Kull, Jr., H. S. Earp, M. E. Svoboda, J. J. Van Wyk, and P. Cuatrecasas. 1983. Somatomedin-C stimulates the phosphorylation of the betasubunit of its own receptor. J. Biol. Chem. 258:9581-9584.

36. Sherr, C. J., C. W. Rettenmier, R. Sacca, M. F. Roussel, A. T. Look, and E. R. Stanley. 1985. The $c$-fms proto-oncogene product is related to the receptor for the mononuclear phagocyte growth factor. Cell. 41:665-676.

37. Sternberg, E. M., J. M. Hill, G. P. Chrousos, T. Kamilaris, S. J. Listwak, P. W. Gold, and R. L. Wilder. 1989. Inflammatory mediator-induced hypotha- 
lamic-pituitary-adrenal axis activation is defective in streptococcal cell wall arthritis-susceptible Lewis rats. Proc. Natl. Acad. Sci. USA. 86:2374-2378.

38. Sternberg, E. M., W. S. Young III, R. Bernardini, A. E. Calogero, G. P. Chrousos, P. W. Gold, and R. L. Wilder. 1989. A central nervous system defect in biosynthesis of corticotropin-releasing hormone is associated with susceptibility to streptococcal cell wall-induced arthritis in Lewis rats. Proc. Natl. Acad. Sci. USA. 86:4771-4775.

39. Smith, C. C., E. Hauser, N. K. Renaud, A. Leff, S. Aksentijevich, G. P. Chrousos, R. L. Wilder, P. W. Gold, and E. M. Sternberg. 1992. Increased hypothalamic [ $3 \mathrm{H}$ ] flunitrazepam binding in hypothalamic-pituitary-adrenal axis hyporesponsive Lewis rats. Brain Res. 569:295-299.

40. Sternberg, E. M., J. R. Glowa, M. A. Smith, A. E. Calogero, S. J. Listwak, S. Aksentijevich, G. P. Chrousos, R. L. Wilder, and P. W. Gold. 1992. Corticotropin releasing hormone related behavioral and neuroendocrine responses in Lewis and Fischer rats. Brain Res. 570:54-60.

41. Aksentijevich, S., H. J. Whitfield, Jr., W. S. Young III, R. L. Wilder, G. P. Chrousos, P. W. Gold, and E. M. Sternberg. 1992. Arthritis-susceptible Lewis rats fail to emerge from the stress non-responsive period. Dev. Brain Res. 65:115-118.

42. Calogero, A. E., E. M. Sternberg, G. Bagby, C. Smith, R. Bernardini, S Aksentijevich, R. L. Wilder, P. W. Gold, and G. P. Chrousos. 1992. Neurotransmitter-induced hypothalamic-pituitary-adrenal responsiveness in inflammatory disease-susceptible Lewis rats. In vivo and in vitro studies suggesting a global defect in CRH secretion. Neuroendocrinology. 55:600-608.

43. Coughlin, S. R., P. J. Barr, L. S. Cousens, L. J. Fretto, and L. T. Williams. 1988. Acidic and basic fibroblast growth factors stimulate tyrosine kinase activity in vivo. J. Biol. Chem. 263:988-993.

44. Kazlauskas, A., and J. A. Cooper. 1989. Autophosphorylation of the PDGF receptor in the kinase insert region regulates interactions with cell proteins. Cell. 58:1121-1123.

45. Coughlin, S. R., J. A. Escobedo, and L. T. Williams. 1989. Role of phosphatidylinositol kinase in PDGF receptor signal transduction. Science (Wash. DC). 243:1191-1194.

46. Kazlauskas, A., C. Ellis, T. Pawson, and J. A. Cooper. 1990. Binding of GAP to activated PDGF receptors. Science (Wash. DC). 247:1578-1581.

47. Kypta, R. M., Y. Goldberg, E. T. Ulug, and S. A. Courtneidge. 1990. Association between the PDGF receptor and members of the src family of tyrosine kinases. Cell. 62:481-492.

48. Ralston, R., and J. M. Bishop. 1985. The product of the protooncogene c-src is modified during the cellular response to platelet-derived growth factor. Proc. Natl. Acad. Sci. USA. 82:7845-7849.

49. Koch, C. A., D. Anderson, M. Moran, C. Ellis, and T. Pawson. 1991. SH2 and SH3 domains: elements that control interactions of cytoplasmic signalling proteins. Science (Wash. DC). 252:668-674. 